http://dx.doi.org/10.12795/PH.1992.v07.i01.11

\title{
EL JURISTA SEVILLANO IBN AL-MAKWI (S. X-XI)
}

Pedro Cano Avila

This manuscript presents the biography of $\mathrm{Abu}$ ' Umar Ibn al-Makwī, an illustrious and outstanding Seville jurist who lived in the 10 th -11 th centuries $\mathrm{AD} / 4$ th -5 th $\mathrm{H}$. In over ten sections into which this study is divided, his biographical details are set out in chronolOgical order and their significance at different points in his life commented on. Worthy of special mention are his taking up residence in Cordoba, the composition of the one and only book that he wrote, and his firm and categorical refusal to accept the post of supreme judge at the end of the Umayyads caliphate. From the juridical standpoint, it is only right to recognize the importance of his learned legal opinions as well as his independence from the political authorities of the time, including the all-powerful Almanzor. Ibn al-Makwi enjoyed the protection and support of a number of prominent figures who maintained a close association with him and who help us to form a better understanding of our man and his time.

Abū 'Umar Ahmad b. 'Abd al-Malik b. Hăšim, al-Išbîtī, al-mālikī, conocido por Ibn al-Makwī (m. ŷumādà $I$ 401/diciembre 1010) ha sido un personaje biografiado por numerosas fuentes árabes' $\mathrm{y}$, además, centro de interés en estudios de carácter jurídico² ${ }^{2}$.

1 Los datos biográficos de Ibn al-Makwī se encuentran en las siguientes fuentes: Al.-Humayir̄, Y̌adwat almuqtabis (El Cairo 1966), 132-133, n. ${ }^{\circ} 231$ (en adelante se citará como YM); 'IYĀp, Tartỉb al-madārik wataqrïb al-masālik, varios editores (Rabat, s.d. -1983), 8 vols., VII, 123-135 (TM); IBN BAŠKuwāı., Kitüb alSila, en F. Codera y J. Ribera (eds.) BAH, I-II (Madrid 1882-83), I, 23-24, n. ${ }^{\circ} 36$; (El Cairo 1966), I, 22 -

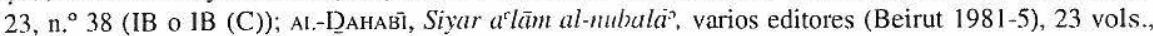
XVII, 206-207, n. ${ }^{\circ} 120$ (SA); y del mismo autor, al-Tharfijabarman gabar, (Kuwait 1970), III, 74-75 (ID); al-Șafadī, al-Wäfi bi-l-wafayät, varios editores (Wiesbaden 1962-1982), 17 vols., VII, 144, n. ${ }^{\circ} 3077$ (WS);

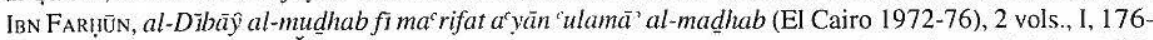
177, n. 53 (DM); MAJtūF, sayarat al-nür al-zakiyya fị tabaqāt al-ntälikiyya (Beirut reimpr. El Cairo 1349- 
Este digno y respetado alfaquí nació en Sevilla en el año 324 H./936 J.C., según nos

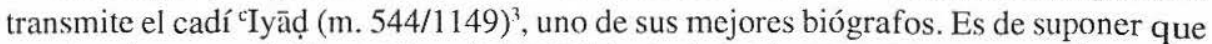
este dato lo tomara de Ibn "Afif (m. 420/1029) ${ }^{4}$ o de al-Qubbašs (m.d. 430/d. 1039) , incluso de Ibn Hiayyān (m. 469/1076) en sus respectivas obras, compuestas con un siglo de antelación a la de 'Iyāḍ. La fecha de

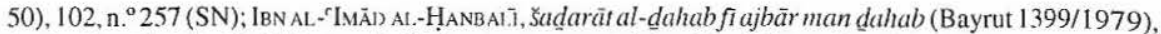

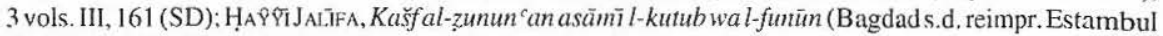

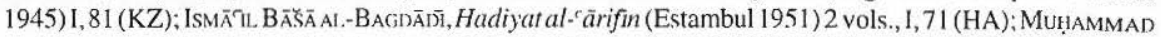

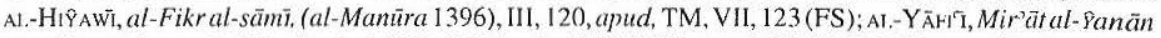

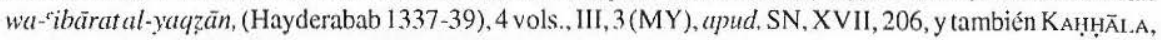
Mu' ýam al-mu'allifin (Damasco 1957-1961), 15 vols., I, 303 (MM), en donde también se encuentra la biografía de Ibn al-Makwi. No podemos dejar de citar una obra importantísima para conocer la actuación juridica de Abū 'Umar que es la de al-Wanšarisī, Mí yär al-mur rib. Hâŷyi et alii, (eds.) (Rabat 1981), 13 vols., III, 115, 116, 124, 126, 128, 346, 411; IV, 23, 72; VI, 86, 220, 267; VII, 432, 435, 436; VIII, 55, 115 , $124,142,175,187,253,260,269,309,319,325,327,330,344$; IX, 40, 41, 123, 169, 197, 206, 224, 381 , 451,$463 ; \mathrm{X}, 232,233,338,350,389,397$.

2 A este personaje lo podemos encontrar citado, con mayor o menor ofrecimiento de datos personales, en los siguientes estudios o trabajos de investigación: M. BF:N CHF:NFB, «Etude sur les personnages mentionnés dans l'Idjâza du cheikh Abd al-Qâdir el-Fâsy» Actes du XIV'tme Congrés International des Orientalistes (Alger 1905), 168-560, concretamente en 478, n. ${ }^{\circ} 288$ (citaré por Personnages); R. CAstisón, Los juristas hispano-musulmanes (Desde la conquista, hasta la caida del califato de Córdoba.-años 711 a 1031 de C.), (Madrid 1948), 135 (Juristas); M. Marín, "La obra genealógica de Ibn 'Abd al-Barr», Actas de las Jornadas de Cultura Arabe e Islámica (1978), (Madrid 1981), 205-229, concretamente 2I8, n. 11 (IAB); M.L. Avir A, «La proclamación (bay a) de Hišăm II, año 976 d.C.», al-Qanțara. I (1980), 79-114, concretamente en 80, 107 (Bay a); de la misma autora, La sociedad hispanomusulmana al final del califato (Aproximación a un estudio demográfico), (Madrid 1985), 110, n. 221 (Sociedad), M.J. VIGU1:RA, «Los jueces de Córdoba en la primera mitad del siglo XI (análisis de datos)», en al-Qantara, V (1984), 123-147 (Jueces), concretamente 128, donde cita a 'Abad Allāh Ibn al-Makwi, hijo de nuestro biografiado; M.I. FIt:RRO y J.ZANon, «Andalusíes en dos obras de al-Dahabĩ: Siyar a'lām al-nubalä’, y Tad̦kirat al-Hịfäz», Estudios Onomástico Biográficos de al-Andalus (E.O.B.A.), I, (Madrid 1988), 183-233; concretamente en 201, n. ${ }^{\circ}$ 60 (Andalusies); E. 1): Fl:LIPł y F. RodríguFz, «La producción intelectual malikí a través de al-Dïbäy almud̆hab de Ibn Farḥün", E.O.B.A., I, 419-527, concretamente en 434, n. ${ }^{\circ} 68$ (Producción).

3 'Iyāộ b. Mũsà b. 'Iyāḍ b. 'Amrūn al-Yahṣubīi al-Saḅ̣i (476-544/1083-1149). Fue una de las más célebres figuras del malikismo en el Magrib. Completó sus estudios en al-Andalus, y ejerció el cargo de cadí en Granada y Ceuta. Véase Encyclopédie de l'Islam nouvelle édition, Leidem-París (en curso de publicación), IV, 302-3, art. por M. TAI BI (E.1. $\left.{ }^{2}\right)$.

4 IBN 'AFĩf. Se trata de Aḥmad b. Muḥammad b. 'Afif b. "Abd Allāh b. Maryuwal b. Ŷarrāḥ b. Ḥătimal-Umawi, al-Qurtubī, Abū 'Umar (348-420/959-1029). Alfaquí experto en la redacción de documentos notariales y autor de un Formulario notarial. Fue discípulo de Ibn Zarb (m. 381/991), Ibn al-Salim (m. 367/978), del cadí Abū l-Muțarrif Ibn al-Ḥașāâr (m. 422/1031) y de Ibn Bartāl (m. 394/1004). Fue un hombre muy piadoso con una rara especialidad: la de lavar y purificar los cuerpos de los difuntos antes de ser enterrados. Escribió un Tratado sobre ese tema en el que describe la actividad a realizar, los diferentes ungüientos que hay que usar, etc. El fue quien lavó el cuerpo de Ibn al-Makwī. El señor de Almería, Jayrān, lo nombró cadí

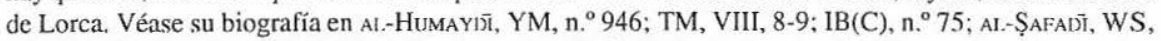
n. ${ }^{\circ}$ 3456; IBN FARHūN, DM, I, 175-6; IBN JAIIIIKĀN, Kitāb Wafayāt al-a $a^{c} y a ̄ n$, I. 'Abbās (ed.) (Beirut 196872), II, 338 (WJ); F. P(Ins BotGuFs, Ensayo bio-bibliográfico sobre los Historiadores y Geógrafos arábigoespañoles, (Madrid 1898), n. ${ }^{\circ} 80$ (Pons); Avila, Bay'a, 90, 98; Avila, Sociedad, n. ${ }^{\circ} 270$.

5. Se trata de al-Hiasan b. Muhammad b. Mufarriŷ b. Ḥammād al-Macāfirī, al-Qubbǎ̌si, Abū Bakr (348-d.430/ 959-d.1039). La biografía de este personaje, conocido también por Ibn Mufarriŷ, la presento en el apartado de Discípulos. 
nacimiento ha llegado hasta nosotros también a través de otro biógrafo de Ibn al-Makwī, concretamente me refiero a Ibn Bas̆kuwāl (m. 578/1 183) ${ }^{7}$, quien nos presenta una completa y sintética biografía en donde se cita precisamente a aquellos tres autores.

\section{SU PRIMERA ÉPOCA}

Carecemos de datos sobre su infancia y juventud por el silencio de las fuentes biográficas, pero, por el contrario, nos informan que fue mawlà de los Banū Umayya; de ello se deduce que podía tener un origen no musulmán y, por tanto, humilde desde un punto de vista social y económico.

Con el paso del tiempo marchó a Córdoba y en ella se estableció. Parece ser que ahí adquirió los conocimientos jurídicos básicos de su mejor maestro, Abū Ibrāhīm, quien había partido de Toledo, de donde era originario, para fijar su residencia en Córdoba; aunque luego regresara y falleciera en Toledo ${ }^{8}$. Como es lógico, completó su formación cultural con las personalidades que residían en aquel tiempo en Córdoba, en su mayor parte; pero no ha llegado hasta nosotros la cita de sus nombres, aunque no es difícil suponerlos. Un hecho que no podemos pasar por alto es que ningún biógrafo afirma que Ibn al-Makwi viajara más allá de las fronteras andalusíes, de ello se podría deducir que su formación fue exclusivamente andalusí.

Abū Ibrāhīm se preocupó de manera especial por la educación y el aprendizaje de Abū 'Umar, conocedor de sus buenas cualidades. Siempre estuvo dispuesto a estimularle y a resolver los problemas que se le pudiesen presentar. Le descubrió el amor al estudio y no dejó de esforzarse en conseguir una firme y sólida cultura para su discípulo. Nos refiere 'Iyād que «al principio tuvo débil mentoria y escasa ciencia, pero Abü Ibrāhīm no cometió errores en el camino a seguir..., hasta que Dios lo iluminó (a Abü 'Umar)»?

Abū 'Umar realizó algunos trabajos en el zoco de los comerciantes de tejidos, pero nunca abandonó su aprendizaje cultural. Atrapado en el ambiente mercantil, practicó como uno más diferentes ardides y actividades tal vez fraudulentas con relativa frecuencia. En cambio, cuando alcanzó un nivel suficiente en su educación, y particu-

6 Hayyān b. Jalaf b. Husayn b. Hayyān, Abū Marwān, conocido por Ibn Hayyān (377-469/987-1076). La biografía de este extraordinario historiador andalusí y las fuentes donde está recogida pueden verse en E.I.? art, por A. HUICI MiRANIDA.

7 Jalaf b. 'Abd al-Malik b. Mascūd b. Mūsa b. Baškuwāl, más conocido por Ibn Baškuwāl (494-578/1 1011183). Es el conocido autor del $k$. al-Sila. Su preparación científica y cultural fue extraordinaria y tuvo lugar fundamentalmente en Córdoba y Sevilla. Recibió también iŷāza-s de algunos orientales. Dedicó su vida al estudio y la enseñanza y llegó a desempeñar el cadiazgo en Sevilla. Murió en Córdoba y allí fue enterrado. Véase E.I. ${ }^{2}$, III, 756, art. por M. Ben CHENFB-A Huici Miranda; H. DEFFl.IPF, y N. TORRFs, «Fuentes y método historiográfico en el Kiłäb al-Ṣila de Ibn Baškuwāl», en E.O.B.A., III. 307-334.

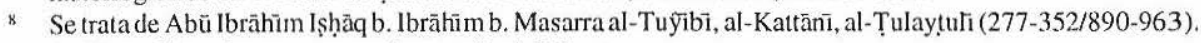
Su biografía está expuesta en el apartado de Maestros.

? 'IYĀ?̣, TM, 123-4. 
larmente en la faceta jurídica, su conducta moral cambió en beneficio de la sociedad y, cómo no, de sí mismo, ya que empezó a gozar de respeto y prestigio entre sus contemporáneos.

Sin duda, ese cambio se debió a los consejos e influencia moral de su maestro toledano, ya que a éste se le reconoce como dotado de una integridad y rectitud dignas de elogio. En el citado ambiente mercantilista se debieron conocer ambos porque Abū Ibrāhìm se dedicaba profesionalmente a las actividades comerciales.

Cuando la gente descubrió la ciencia que atesoraba Abū ${ }^{c} U$ mar y la habilidad que demostraba al aplicarla, se vio necesitada de acudir ante él y solicitar sus fétuas o dictámenes jurídicos.

Todos sus biógrafos coinciden en elogiar sus grandes conocimientos del derecho malikí, y la rectitud y habilidad empleadas en su actividad jurídica. Su prodigiosa memoria, admirada y envidiada por todos, fue puesta a prueba en más de una ocasión, saliendo naturalmente triunfadora. El propio cadí supremo Ibn Zarb llegó a decir en cierta ocasión: «iCompañeros! La verdad es superior a lo que se dice de él; $A b \bar{b}^{c} U$ mar ha hecho que todos nosotros apreciemos el valor de la memoria».

Al-Qubbašsı nos trasmite que sus propios compañeros reconocían esta virtud diciendo: «Abū 'Umar al-Makwī hizo que aprendiéramos de memoria muchos elementos relacionados con la ciencia». En otra ocasión, precisamente sobre la tumba de nuestro personaje el día de su entierro, uno de sus alumnos más fieles, Ibn al-Saqqāq, dijo: «¡Dios tenga misericordia de ti Abū 'Umar!, puesto que desenmascaraste a los alfaquíes mientras tuviste vida con el poder de tu memoria, y sigues haciéndolo después de tu muerte. Yo doy testimonio de que no he visto nunca a nadie memorizar la Sunna, como lo has hecho tú, y de que nadie ha conocido sus aspectos más difíciles como tú».

Además de referirse a su memoria, estas manifestaciones también son ejemplo de su personalidad, puesto que nos indican que daba a cada cual lo que le correspondía. Sus biógrafos inciden en este aspecto de su personalidad: su sinceridad y valentía al mantenerla en aquella época crítica. No acostumbraba a someterse, no ocultaba su opinión en busca de la verdad, dejándose guiar por una idea básica: la de acercarse a la verdad alejándose siempre de los extremos y situándose en el centro. Por esta misma razón nunca engañó con halagos a la autoridad, ni tuvo ambiciones políticas.

Ibn 'Afif añade, en relación con su personalidad, que fue muy sólido en sus creencias, muy firme en sus opiniones y muy discreto en sus deseos o caprichos personales. También se afirma que tenía un gran entendimiento, agudeza mental, sagacidad y perspicacia. Todas esas cualidades se pueden observar en los extraordinarios y curiosos asuntos tratados en sus dictámenes jurídicos.

El historiador Ibn Ḥayyān dijo que Ibn al-Makwī, en esta primera época de aprendizaje, no se preocupó mucho por instruirse en lengua árabe. Esta deficiencia, por lo tanto, se dejó notar en la redacción de sus fétuas, ya que aparecieron algunas faltas gramaticales que extrañaban y eran motivo de rechazo por parte de sus compañeros. Pero el problema lo solucionó él mismo, cuando se recluyó en su domicilio durante un mes completo, haciendo 
creer que padecía una enfermedad, para dedicarse al intenso estudio del libro que Sibawayhi ${ }^{10}$ había compuesto sobre la lengua árabe y su correcto uso. Adquirió, por lo tanto, los suficientes conocimientos gramaticales para no volver a cometer nuevos errores, gracias a su excelente memoria.

\section{LA OBRA}

Sus biógrafos mencionan a Ibn al-Makwī como autor de una sola obra ${ }^{11}$, que además fue elaborada en compañía de otro ilustre personaje, Abū Bakr al-Qurašsı al-Mưcayț ${ }^{12}$. El título de la misma es generalmente citado así: Kitāb al-Istic $\bar{a} b$, es decir, el Libro del abarcamiento total. Sin embargo, se encuentran estas variantes:

Kitāb al-Istī $\bar{a} b$ al-Kabìr.

Kitāb al-Istī āb fì madhab Mālik.

Kitāb al-Istī āb fí ra'y Mälik.

Kitāb al-Istĩ $\bar{a}$ b li-qawl Mälik, y

Kitāb al-Istī āb fíl-fiqh al-mālikī.

Se trata de un libro cuya materia está contenida en los $F u r \bar{u}^{c}$ al-fiqh, es decir, la ciencia que desarrolla y aplica los fundamentos del derecho musulmán. La composición de este libro había sido ordenada por el califa andalusí al-Ḥakam II (m. 366/976), quien deseaba se recogieran todas las decisiones y opiniones del epónimo de la escuela jurídica malikí. Comenzaron la redacción algunos compañeros del cadí Ismācill, entre ellos Ibn Ajī Rabīi al-Șabbāg ${ }^{13}$, quienes acordaron realizar un dīwān general que contuviera todas las opiniones de Mālik b. Anas de forma particular, sin que se incluyeran las opiniones de ninguno de sus seguidores. Se llegaron a realizar cinco secciones aproximadamente, pero el autor cayó agotado por su deseo de terminarlo pronto y de manera rigurosa. El proyecto quedó sin realizar a pesar del ardiente deseo del califa de su terminación por la utilidad que reportaba.

10 Abū Bišr ' Amr b. ' Uțmān b. Qanbar (m. aprox. 177/793). Eminente gramático de la escuela de Baṣra autor de una obra conocida genéricamente por al-Kitäb.E.I. ${ }^{1}$, VII, 397-8 (ed. inglesa, Leiden 1987), art. por F. KRI:NKOW.

"Desconocemos si en la actualidad se conserva en alguna biblioteca o cualquier otro sitio. AL-ḤumAYDī (m. 488/1095), tiene un error al citar otra obra, titulada al-Bähir, como escrita por Ibn al-Makw̌w. YM, n. ${ }^{\circ} 231$.

12 Abū Bakr Muḥammadb. 'Ubayd Allāh b, al-Walid b. Muḥammad al-Qurašs̃al-Mưaỵ̣ (329-367/940-978). Miembro de una noble familia de jurisperitos. Tuvo por maestros a su propio padre, a Wahb b. Masarra, Jălid b. Sa`id y a Abū Ibrāhīm al-Țulaytuli, entre otros. Experto en fiqh, excelente conocedor de las opiniones malikíes. Hombre piadoso que al final de su vida decidió convertirse en cenobita y aislarse del mundo. IBN AL-FARAḌ̂, $T a^{3} r i \bar{j} c^{c}$ ulama $\vec{a}^{3}$ al-Andalus, (El Cairo 1966) n. ${ }^{\circ} 1.320$ (en adelante $I F(C)$ ); $T M$, VII, 119-122; DM, II, 225-6; SN, n. ${ }^{\circ} 242$; Avil.A, Bay a, 80; Avil.A, Sociedad, n. ${ }^{\circ} 817$; L. Molina, «Familias andalusíes: los datos del $T a^{3} r i j{ }^{~}$ 'ulamä' al-Andalus de Ibn al-Faraḍi. II», E.O.B.A., III, 13-58, especialmente 53 .

13 Abū Muhammad 'Abd Allāh b. Muḥammad b. Ḥunayn (o H̦usayn) al-Kilābī (o al-Kila`i), conocido por Ibn Ajı Rabī al-Şabbag (m. en 318 ó 319/931 ó 932). Véase su biografía en TM, V, 211-2; M. MARín, «Nómina de sabios de al-Andalus (93-350/711-961)", E.O.B.A. I, 23-182, concretamente n. 809 (Nómina). 
Al cabo de los años el califa quiso que se reiniciaran los trabajos y, después de comentarlo con el cadí supremo de Córdoba, que a la sazón era Ibn al-Salīm, se ocuparon del proyecto dos conocidos alfaquíes, Abū Bakr al-Qurašsı al-Mưayți y Abū 'Umar Ibn al-Makwī. Pero el cadí impuso una condición al califa: que permitiera utilizar los fondos bibliográficos de su biblioteca a esos alfaquíes. El califa respondió afirmativamente a pesar de su cicatería. Así pues, pudieron terminar la obra que tanto ansiaba al-Ḥakam II, recopilando todas las opiniones de Mälik sin importar su cadena de transmisión, por lo que se recogieron los datos proporcionados por mequíes, medineses, iraquíes, egipcios, norteafricanos, andalusíes y otros, ayudados por un grupo de personas. Todo ello alcanzó una cifra de cien partes o secciones.

La redacción del libro se vio acompañada por un problema de celos entre ambos autores. Ibn al-Makwī, con 40 años aproximadamente, y al-Quraši, yerno del cadí y con 35 años aproximadamente, atesoraban casi los mismos conocimientos, pero entre ellos surgió una disputa por su aportación particular a la obra, que sólo fue resuelta con la intervención del califa. Este se mostró favorable a al-Quraši, hecho que aumentó la enemistad surgida entre ambos y requirió la intervención conciliatoria del cadí. A la conclusión del libro todos se sintieron muy satisfechos, por lo que el califa premió la labor realizada con mil dinares para cada uno de los dos autores, el nombramiento como nuevos miembros de la šürà cordobesa y el turbante.

\section{NOMBRAMIENTO DE MUŠ̈AAR}

Resulta evidente que los méritos científicos y personales de Ibn al-Makwi eran suficientes para recibir el título oficial de mušāwar o consejero jurídico del califato; pero la razón última que posibilitó este hecho fue la composición del Kitāa $a l-I s t \bar{t} a \bar{a} b a l-k a b \bar{i} r$, considerado como la mejor obra de todas las que se escribieron en al-Andalus en aquel tiempo. Sin duda, ello contribuyó a elevar su prestigio en el califato ${ }^{14}$.

La fecha del nombramiento no se sabe con certeza porque, si bien se dice por una parte que sucedió en 365/976, por la intervención favorable del cadí supremo Ibn al-Salim, nombrado para tal cargo en 356/967; también por otra parte se nos dice que al-Qură̌̀ recibió tal nombramiento cuando tenía treinta años, es decir, en 359/970, y ya sabemos que ambos fueron nombrados a la vez.

De la šürà podemos decir que en aquella época estaba integrada por los siguientes juristas:

Ibn Zarb (m. 381/991).

Al-Așili (m. 392/1002).

Al-Watad (m. 397/1007).

14 Sobre la šürà, véase M. MARín, «Šürà et ahl al-šūrà dans al-Andalus», Studia Islamica, LXI-LXII (1985), 25-5I (šūrà). 
Ibn al-Maššătit (m. 397/1007).

Aṣbag b. al-Faraŷ al-Ṭā̄ìn. 397/1007).

Ibn al-"Attār (m. 399/1009).

Ibn Wāfid (m. 404/1014).

Abū l-'Abbās Ibn Dַakwān (m. 413/1022).

Abū l-Ḥātim Ibn Dakwān (m. 414/1023).

Ibn al-Ṣaffăr (m. 429/1038).

A ellos se unieron al-Qurašs (m. 367/978) e Ibn al-Makwī (m. 401/1010).

Como tendremos ocasión de comprohar más adelante, muchos de ellos llegaron a ejercer el cargo de cadí supremo y, por otra parte, fueron víctimas de Ibn $\mathrm{Abīi}^{\mathrm{c}} \mathrm{A} m i r(\mathrm{~m}$. 392/1002) en el gobicrno del califato, entre otros asuntos, por el de la oración del viernes en la mezquita de al-Zāhira ${ }^{15}$. El lugar que dejó vacante en la šürà Ibn al-Makwī a su muerte fue ocupado por Abū l-'Abbās al-Bāgān̄̄ito.

El reconocimiento de la elevada categoría jurídica y personal de nuestro personaje se nos manifiesta con la intención de Almanzor por nombrarlo cadí supremo de Córdoba. En dos ocasiones se le convocó para ejercer tal cargo; la primera de ellas para suceder a Abū Bakr Ibn Zarb, con motivo de su fallecimiento en 381/991; y la segunda, diez años y medio después, al destituir Almanzor de tan alto cargo a su propio tío Ibn Bartāl en diciembre de 1001, personaje que, por otra parte, poseía una gran experiencia en cuestiones judiciales. En ambas ocasiones rechazó el of recimiento con una firme negativa y, además, pronunció solemnemente el juramento de no desempeñar nunca el cadiazgo ni otro cargo de parecida categoría relacionado con la administración de justicia. La causa pudo ser probablemente la vida política del momento.

\section{ACTIVIDAD JURÍIJICA}

Según sus biógrafos, Abū cUmar llegó a ser uno de los más reconocidos muftíes de alAndalus, puesto que los conocimientos jurídicos que atesoraba le llevaron a la dirección de esta ciencia en su época. Ha llegado incluso a ser comparado con el gran jurista Yahyà b. Yahyàa ${ }^{17}$, quien controló rigurosamente la implantación y el desarrollo de la ciencia jurídica malikí en la época del emir "Abd al-Raḥmān II, con la aprobación de éste.

is AvII. A, Baýa, 107-108; IBN AI.-'ATTTĀe, Formulario, introd. XVI, XVIII.

16 Ahmad b. 'A

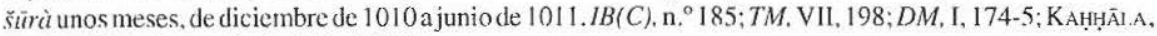
MM, 1, 316: Avil.n. Sociedud, n. 231.

17 Abū Muhammad y Abū Tsà Yahyyà b. Yaḥyà b. Kaṭir al-Laỵ̣̂i (147-234/764-849). Alfaquí cordobés de origen beréber que logró implantar y controlar en al-Andalus la jurisprudencia malikí. Discípulo de los mejores maestros malikíes y del propio Mālik. Transmitió de él su Muwattt( ${ }^{3}$. Recogió las enseñanzas de Ibn al-Qāsim en diez. libros conocidos por el título de 'Ašarat Yahycà. Véase, entre otros, E.J. ${ }^{2}, 1,8.5$, s.v., 'Abd al-Ral!mūn, art. por E. LIVII-PRovinNÇAI.. 
Desde este lugar de privilegio emitió dictámenes jurídicos sobre los más diferentes asuntos, y aconscjó a compañeros, jueces y autoridades en general, sobre la forma de resolver cuestiones jurídicas y actuar con arreglo a la ley sagrada. Se convirtió inevitablemente en alguien a quien consultar cuando entre cadíes y magistrados andalusíes existían graves discrepancias. Los principios que utilizó fueron siempre los propios de la escuela malikí, pero sobre todo el $r a^{3} y$, común también a otras escuelas y que, como sabemos, se trata de la opinión personal o conclusión adoptada a tenor de un razonamiento sistemático individual. Desde esta perspectiva, se dice que cada lunes explicaba y comentaba el Kitāb al-Muwațta ${ }^{318}$, y el martes la Mudawwana ${ }^{19}$ y la Mustajraŷa ${ }^{20}$.

Se afirma que no le dio alcance ninguno de los mejores de su época en el conocimiento de las opiones de Mālik, ni de los distintos maestros de la escuela malikí. También explicaba las diferencias de opinión existentes entre ellos y su propia preferencia personal.

Existen numerosas anécdotas sobre su memoria y sobre sus conocimientos como la siguiente: El cadí Ibn Zarb en una ocasión formuló una cuestión jurídica difícil que dejó perplejos a varios alfaquíes, pero Ibn al-Makwīintervino diciendo que la recordaba y, es más, que se encontraba en tal libro y en tal capítulo, siendo su final tal solución jurídica. Acto seguido el cadí ordenó traer ese libro y resultó que ¡allí estaba lo que él había dicho!

En otra ocasión, los propios miembros del Consejo (Maŷlis) le presentaron una cuestión cuyas palabras habían escogido minuciosamente para hacer aún más difícil su comprensión. Cada uno de esos memoriones intervino utilizando desusados vocablos y extrañas frases, pero $A b \overline{\text { }}$ "Umar guardó silencio para escucharles y, cuando agotaron sus intervenciones, respondió a cada uno con arreglo a las insólitas cuestiones planteadas, como si estuviera observando la página de un libro. Ello fue motivo de admiración y, por lo tanto, se acrecentó su prestigio personal.

Sobre la actividad jurídica de Ibn al-Makwi existen muchos ejemplos que nos relatan sus biógrafos ya citados, incluso conocemos las cuestiones que se le formularon, gracias a al-Wanšarīî̀. Todas ellas fueron respondidas de forma breve y clara, y además en corto espacio de tiempo. Los temas tratados en sus fétuas son variados y descienden hasta el pequeño detalle, que puede variar el resultado final del dictamen jurídico. Entre otros se pueden destacar los relacionados con el contrato matrimonial, con la dote en especial; con la compraventa de una muchacha esclava hija de una mujer libre; con la compraventa de bienes en régimen de copropiedad; también el asunto de la negativa al reconocimiento de

1s Se trata de la obra compuesta por Mâlik b. Anas, fundador de la escuela jurídica malikí. Uno de los más antiguos libros de jurisprudencia musulmana con gran influencia en al-Andalus. Esta obra, que contiene la doctrina juridica malikí, fue redactada por Saḥnūn (m. 240/854) según las respuestas dadas por lbn al-Qāsim (m. 191/806) a las cuestiones jurídicas que le eran planteadas por sus discípulos.

10) Obra conocida también por al-`Utbivyła, cuyo autor fue el jurista malikí cordobés Muhammad b. Ahmad b. 'Abd al-"Aziz, conocido por Al-'Uṭí (m. 255/869). Una de las cinco grandes obras del malikismo. 
paternidad; o el asunto de la reivindicación de bienes o esclavos, etc. Pero a pesar del interés que muestran todos estos temas, las limitaciones de espacio, entre otras, nos impiden ofrecer aquí la edición y la traducción de los mismos.

\section{MAESTROS}

El único maestro citado expresamente por las fuentes biográficas es Abū Ibrāhīm Isḥāq b. Ibrāhīm b. Masarra al-Tuỹìbī al-Kattānī, al-Țulaytulī (277-352/890-963) ${ }^{21}$. Suponemos que instruirían también a nuestro personaje otros muchos maestros residentes en Sevilla primero y en Córdoba después. Sus biógrafos nos informan que era cordobés, aunque señalan que sus orígenes inmediatos eran toledanos. En Córdoba estudió con sus mejores maestros, algunos de los cuales fueron Muhammad b. 'Umar b. Lubāba (m.314/ 926), Ibn Aymān (m. 330/941) y Qāsim b. Aṣbag (m. 340/951). Fue häfiž maliki, mušāāwar y niuft $t$. Se dice que no era experto en hadit y que fue autor de un libro titulado Kitäb alNașāih (Libro de los Buenos Consejos). Este personaje estuvo dotado de profundo espíritu religioso y grandes virtudes. En Córdoba practicó el comercio y se entregó al estudio de la ciencia. Se mantenía alejado e independiente de las autoridades, pero el califa al-Ḥakam II le tenía en muy alta estima. En determinado momento se marchó a Toledo y allí falleció en raŷab de 352/agosto de 963, a la edad de setenta y cinco años.

\section{JURISTAS CONTEMPORÁNEOS}

Presento a continuación determinados personajes particularmente destacados en la sociedad andalusí de la época de Ibn al-Makwī, es decir, el final del califato. Todos ellos están relacionados de una manera directa con Abū 'Umar, puesto que lo conocieron y compartieron con él maestros, ciencia y actividad profesional.

Además de éstos, he considerado oportuno incluir en este trabajo una pequeña biografía de dos extraordinarios alfaquíes malikíes norteafricanos, Ibn Abī Zayd alQayrawānī y Abū 1-Ḥasan al-Qābisī. Lo he creido conveniente por evidentes razones, como la época en que vivieron, la especialidad de sus conocimientos y actividades, y por ser maestros de varios de los andalusíes que aquí muestro.

21 Véase su biografía en IF(C), n. 235 ; Al-DABBI, Bugyat al-multamis fita'rīj riŷâl ahl al-Andalus, F. ConF,RA y J. RibFra, (eds.) en B.A.H., (Madrid 1884-5), III, n. 551 (D); TM. VI, 126-134; YM, n. ${ }^{\circ} 305 ;$; M, I, $296-$ 7; SA, XVI, 79-80; n. ${ }^{\circ} 61 ;$;N , n. ${ }^{\circ} 199$; Marín, Sürà, 42; Fifrro/Zanon, Andalusíes, n. ${ }^{\circ} 159 ;$ Avil.A, Sociedad, n. ${ }^{\circ}$ 532; J. CASTII.LA, «A Ạmad ibn "Afif», en E.O.B.A., IV, 113-145, especialmente, 119 y 129. 


\section{En al-Andalus}

1. 'Abd Allāh b. Ibrāhīm b. Muhammad b. "Abd Allāh b. Yacfar al-Aṣ̂ilì, Abū Muhammad, conocido por al-Așili (324-392/936-1002)22. Viajó a Oriente y visitó las principales ciudades de Iraq en busca de ciencia. Fue discípulo de Abū l-Ḥasan al-Qābis̄ị y de Ibn Abī Zayd al-Qayrawānī en el Norte de Africa y de Abū Ibrāhīm b. Masarra alȚulaytuli en al-Andalus, el maestro por excelencia de Ibn al-Makwī. Este alfaquí fue autor de un šarh al-Muwațtā̄' muy elogiado y uno de los miembros de la šürà.

2. Muḥammad b. "Abd Allāh b. "isà b. Muḥammad al-Murrī, al-Ilbīrī, Abū cAbd Allāh, conocido por Ibn Abī Zamanīn al-Ilbīìi (324-399/936-1009)23. Formaba parte de una familia dedicada al estudio de la jurisprudencia y la religión, de la que él llegó a ser el miembro más representativo. Su formación científica tuvo lugar exclusivamente en alAndalus, donde fue alumno de Isḥāq b. Ibrāhīm (m. 352/963) y de Ibn Masarra (m. 346/ 857), entre otros. No fue un simple recopilador de jurisprudencia malikí. Autor de varios tratados jurídicos, de los que destacamos el Muštamal fî- ușūl al-wațā̄i $i q$, compuesto sobre escrituras notariales.

3. Aḥmad b. Sa'îd b. Ibrāhīm al-Hamadān̄i, Abū 'Umar, conocido por Ibn al-Hindī (320-399/932-1009)24. Discípulo de Qāsim b. Așbag, Ibn Masarra, y de Abū Ibrāhīm. Personaje interesado en la jurisprudencia y la historia de al-Andalus, campos en los que llegó a ser considerado como hạafiz. También fue experto redactor de instrumentos públicos y autor de un $K$. al-wațā'iq muy utilizado en al-Andalus y al-Magrib.

4. Muhammad b. Aḥmad b. 'Ubayd Allāh b. Sa'id al-Umawī, Abū 'Abd Allāh, conocido por Ibn al-'Atțār (330-399/942-1009) ${ }^{25}$, Muftī, mušăwar y experto en la redacción de actas notariales. Coincidió con Ibn al-Makwī en la šürà, pero nunca se enfrentó a él. Su mal carácter le proporcionó numerosos y poderosos enemigos, como el propio cadí supremo Ibn Zarb o el hậ̄ìib Ibn Abī 'Āmir. Fue destituído de sus cargos públicos y

22 Véase $I F(C)$ n. ${ }^{\circ} 760 ; Y M$, n. $^{\circ} 542 ; T M$, VII, 135-145; IBN JAYr, I, 27I; D. n. ${ }^{\circ} 906 ; D M, 1,433,435 ; S N$, n. $^{\circ}$

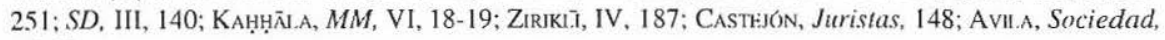
n. ${ }^{\circ} 45$.

${ }^{23}$ Véase $Y M, 56-7, \mathrm{n}{ }^{\circ} 57 ; T M$, VII, 183-6; IBN JAYR, 251, 288-9; IB(C), n. ${ }^{\circ} 1047 ; \mathrm{D}, \mathrm{n},{ }^{\circ} 160 ; D M$, II, 232-3; $S N$, n. $^{\circ} 252 ; S D$, III, 156; SA, n. ${ }^{\circ} 177$; ZIRIKI.̄̄, VII, 101; KAHHÄI.A, $M M, X, 229-230$; Pons, n. ${ }^{\circ} 64$; WS, III, n. ${ }^{\circ}$ 1374; E.I. ${ }^{2}$, III, 716; M. ArCas CAMPOY, «Ibn Abi Zamanin y su obra jurídica», Cuadernos de Historia del Islam, 11 (1984), 87-101.

24 Véase TM. VII, 146-7; IBN JAYR, 252; IB (C). n. ${ }^{\circ} 21$; IBN SA'in, al-Mugrib fi hulà al-Magrib, en š. Ḍayf (ed.)

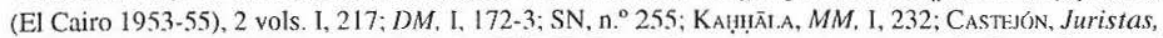
140-1, 175; Pons, n. ${ }^{\circ}$ 65; Avi .A, Sociedad, n. ${ }^{\circ} 337$; P. Cano, Contratos conmutativos en la Granada nazarí del siglo XIV, según el Formulario notarial de Ibn Salmün (m. 767/1366), Univ. de Granada (Granada 1987), 2 vols. II, 676 (C. connutativos).

25 Véase $I F, \mathrm{n} .{ }^{\circ} 1667 ; T M$, VII, 148-158; $I B(C)$, n. ${ }^{\circ} 1048 ; D M$. II, 231; SN, n. ${ }^{\circ} 254 ;$ AL-NuBĀHĪ, Kitäbal-marqaba al-'ulya fi man yastahiqqu al-qaḍā' wa-l-futyà, en E. Lévi-Provençal (ed.) (El Cairo 1948), 77, 87 (MU);

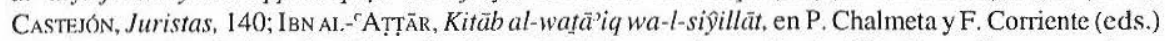
(Madrid 1983), en la introducción realizada por P. Chalmeta; Avil.A, Bay'a, 107; Cano, C. conmutativos, II, 669. 
recluído en su casa. Realizó un viaje a Oriente y estudió, entre otros, con Ibn Abī Zayd al-Qayrawān̄̄. Autor de un Formulario notarial muy alabado y utilizado, cuyo título es Kitāb al-wațā'iq wa-l-siŷillāt.

5. 'Abd Allāh b. Muhammad b. Yūsuf b. Nașr, Abū 1-Walìd, conocido por Ibn alFaraḍi (351-403/962-1013) ${ }^{26}$. Célebre cordobés experto en derecho, tradición, literatura c historia. Entre sus maestros se encuentran el cadí Ibn al-Jarrāz, Ibn Abī Zayd y al-Qābisī . Viajó a Oriente, realizó la peregrinación y a su vuelta fue nombrado cadí de Valencia. Transmitió la Risāla de Ibn Abī Zayd al-Qayrawān̄̄ a su alumno Ibn 'Abd al-Barr y fue autor de la conocida obra biográfica titulada $T a^{3} r^{3}{ }^{c} u l a m i \bar{a}^{\urcorner}$al-Andalus. Murió a manos de los beréberes en su propia casa.

6. Muhammad b. 'Umar b. Yūsuf al-Mālikī, Abū 'Abd Allāh, conocido por Ibn alFajjār (343-419/954-1028)27. Alfaquí, mušăwar, tradicionista y hăfiz cordobés, con decisiva influencia en al-Andalus y al-Magrib. Viajó a Oriente y residió durante algún tiempo en Medina. Parece ser que fue alumno de Ibn al-'Attāar, Ibn Ab̄̄ Zayd y de alQābisī. Autor de varias obras, entre las que destacamos un resumen del K. al-Nawädir de Ibn Abì Zayd y un tratado de Derecho notarial ('ilm al-wat $\bar{a}^{\prime} i q$ ), materia en la que fue un gran experto. Se destacó por su firme oposición a los beréberes.

\section{Fuera de al-Andalus}

1. 'Abd Allāh b. Ab̄̄ Zayd 'Abd al-Rahmān al-Qayrawān̄ī, Abū Muhammad, más conocido por Ibn Abī Zayd al-Qayrawānī (m. 386/996) ${ }^{28}$. Alfaquí, exégeta y mufassar nacido en Nafza, aunque su residencia habitual estuviera en Qayrawān. Por sus grandes conocimientos fue llamado «el pequeño Mālik», y gracias también a ellos se situó al frente de la escuela malikí de esa ciudad y del Norte de Africa en general. Ejerció una sobresaliente influencia en al-Andalus, tanto por vía oral como escrita. Algunos de sus discípulos se encuentran en este trabajo. Compuso numerosas obras entre las que hay que destacar el Kitāb al-Nawādir, el Mujtașar al-Mudawwana y su celebérrima Risāla.

2. 'Alı̄ b. Muhammad b. Jalaf al-Ma'āfirī, más conocido por Abū 1-Hasan al-Qābis̄̄ (324-403/936-1013) ${ }^{29}$. Alfaquí que dirigió los destinos de la escuela malikí a la muerte de

26. Véase $Y M, \mathrm{n} .^{\circ} 537, I B(C), \mathrm{n} .^{\circ} 572 ; D, \mathrm{n} .^{\circ} 888 ; D M, \mathrm{I}, 452 ; S N, \mathrm{n},{ }^{\circ} 261 ;$ Pons, $\mathrm{n} .{ }^{\circ} 71 ;$ Marín, IAB. 216; E.I. ${ }^{2}$, III, 785, art. por Ben CHinFi-HUICI Miranda.

27 Véase $I B(C), \mathrm{n}^{\circ} 1113 ; T M$, VII, 286-9; $D, \mathrm{n}^{\circ} 221 ; D M, \mathrm{II}, 235-6 ; S N, \mathrm{n}^{\circ} 301 ; S A, \mathrm{XVII}, 372-4, \mathrm{n}^{\circ} 234 ; S D$, III, 213-4; WS, IV, 245; AvII.A, Sociedad, n. ${ }^{\circ} 826$; Avll.A, Bay a, 89; CANo, C. conmutativos, II, 671-2.

Véase TM. VI, 215-222; IBN JAYR, 244, 246-247; DM, I, 427-430; ZIRIKI.̄̄, IV, 230; KAHHĀI.A, MM, VI, 73; GAL, I, 77, S. I, 301, 302; GAS, I, 478-481; Ben Chr:nF: Personnages, 498-500, n. ${ }^{\circ} 322$; FóRnEas, Elencos biobibliográficos arábigoandaluces. Tesis Doctoral (Madrid 1971), 49, 50(Elencos); B.M., FAH, «Ibn Abī Zayd al-Qayrawān̄̄ 386 h. 1996», Awrūq. V-VI (1982-1983), sección árabe, 31-41; R. Aréval.o, Derecho penal islámico. Escuela Malekita, Tánger 1939, 184-185; E.I. ${ }^{2}$, III, 717, art. por H.R. IDRIS.

29 Véase DM, II, 101-102; KAIIIĀI.A, MM, VII, 194-195; ZirikI.̄, V, 145; GAL. S.I., 277; GAS, I, 482-483; Fórneas, Elencos, 49; D. SANTII.IAna, Istituzioni di Diritto Musulmano Malichita con riguardo anché al 
Ibn Abī Zayd. Se distinguió por su prodigiosa memoria y sus profundos conocimientos de los $F u r u^{c}$, de los $U s ̦ u ̈ l$ y del Ḥadịt. Viajó a Oriente en busca de ciencia y compuso numerosas obras de tema jurídico-religioso, donde se observa la influencia de Ibn al-Mawwāz ${ }^{30}$. Como muestra citaré la titulada Kitāb al-mulajjiș li-musnad Muwațtāo Mālik b. Anas, muy apreciada tanto en Ifrīiya como en al-Andalus, y el Kitāb al-Munabbih li-duway al-jatan 'alà gawā’il al-fitan, transmitido por Ibn al-Faraḍ̂i a su alumno Ibn 'Abd al-Barr.

\section{Cadies supremos de Córdoba contemporáneos}

Estos juristas andalusíes ejercieron el cargo más elevado de la jerarquía judicial, el cadiazgo supremo, a veces, como veremos, por partida doble. Algunos de ellos tuvieron que realizar un esfuerzo especial para aceptar tal cargo, tal vez por la gran responsabilidad que ello suponía, por el descrédito que sufría la institución, o por otras razones. Hubo quienes se negaron rotundamente a ejercerlo, como Abū 'Umar Ibn al-Makwī, a pesar de tener suficientes conocimientos jurídicos, prestigio personal y categoría social.

Presento, por consiguiente, a contemporáneos de Ibn al-Makwī con la doble característica de juristas y cadíes, que se relacionaron directamente con él, que buscaron frecuentemente su consejo y apoyo, y estuvieron a merced de los vaivenes políticos de la época, sobre todo los últimos cadíes que presento, incluido su propio hijo.

1. Muḥammad b. Isḥāq b. Mundir b. Ibrāhīm, Abū Bakr, más conocido por Ibn alSalim (302-367/914-978) ${ }^{31}$. Aunque fue criticado en el ejercicio del cargo de cadí supremo por su incapacidad, se mantuvo en él durante once años, desde 356/967 hasta su muerte en 978. En algunas ocasiones se enfrentó a Almanzor. Fue quien encargó de forma directa a Ibn al-Makwī la elaboración del Kitāb al-Istĩ äb,y quien lo nombró, o al menos intercedió para conseguir su nombramiento, como uno más de los miembros de la šūrà de Córdoba, junto a Abū Bakr al-Mưaỵ̣i. Este hecho sucedió después de terminar el citado libro.

2. Muḥammad b. Yabqà b. Muḥammad b. Zarb b. Yaz̄id al-Qurțubī, Abū Bakr,

sistema sciafiita, (Roma 1926-1938), 2 vols., II, 654; H.R. IDRIS, «Deux juristes kairouanais de l'époque ziride: Ibn Abī Zayd et al-Qābis̄ì, Annales de l'Institut des Études Orientales, XII (1954), 121-198; M. TAL.BI, «Kairouan et le malikisme espagnol», Études d'Orientalisme dédiées à la mémoire de Lévi-Provençal. (París 1962), I, 317-337.

30 Se trata de Muhammad b. Ibrāhūm b. Ziyād al-Iskandārī, Abū cAbd Allāh (m. 269/883). Célebre alfaquí egipcio que tuvo decisiva influencia en los malikíes a través de su obra, conocida vulgarmente como la Mawwäzīya. Véase TM, IV, 167-170; DM, II, 166, ZIRIKI.T, VI, 183; KAḤ̣ĀI.A, MM, VIII, 200; GAS, I, 474; GAL, S.I., 300; CASTH'Jón, Juristas, 96.

3. Véase $I F(C)$, n. ${ }^{\circ} 1319 ; T M$, VI, 280-9; DM, II, 214-6; Al-SuYūTī, Bugyat al-wú āt fi tabaqāt al-lugawīyyin wa-l-nuhūt, en M.A. Ibrāhīm (ed.) (El Cairo 1964) 2 vols, I, 13;SN, n. ${ }^{\circ} 239 ; S A, X V I, 243-4$, n. ${ }^{\circ} 170 ; S D$. III, 60; E. Lívi-ProvençAl., Historia de la España musulmana, vol. IV de la Historia de España dirigida por R. Menéndez Pidal (Madrid 1987), 408; Avir.A, Baýa, 84, 94, 99-103, 107, 110, 112; Avil.A, Sociedad, n. ${ }^{\circ} 753$. 
conocido por Ibn Zarb (317-381/929-991) ${ }^{32}$. Alfaquí cordobés de gran prestigio entre sus compañeros. Llegó a ser temido por su rectitud e intransigencia doctrinal, empleadas en la lucha contra Ibn Masarra. Tubo gran ascendencia en Almanzor, a pesar de la oposición del cadí a que se celebrara la oración del viernes en al-Zāhira. Alumno de Qāsim b. Aṣbag (m. 340/951), de Ibn Abī Dulaym (m. 338/949) y de Abū Ibrāhīm. Fue autor de la obra jurídica titulada Kitāb al-Jișăl fî-l-furǘ al-mālikìya y ocupó el cargo de cadí supremo desde 978 hasta su muerte en 991.

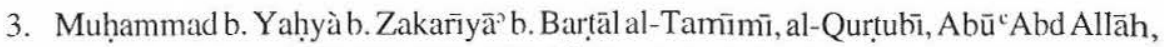
conocido por Ibn Bartāal (299-394/91 1-1004) ${ }^{33}$. En al-Andalus fue alumno, entre otros, de Aḥmad b. Jālid y Qāsim b. Aṣbag. Realizó la peregrinación y aprovechó el viaje para estudiar y completar su formación con los maestros norteafricanos y orientales. Ocupó el cargo de cadí en Rayya (Málaga) y Jaén antes de ser nombrado cadí supremo en Córdoba, cargo que desempeñó durante diez años y medio, de 991 a 1001. Fue tío de Almanzor y protector de Ibn alcAțāra a quien encargó la redacción de su Formulario notarial.

4. Aḥmad b. “Abd Allāh b. Hạartama b. Dakwān, Abū 1-'Abbās, conocido por Ibn Dakwān (342-413/953-1022) ${ }^{34}$. Se trata del miembro más célebre de los Banū Dַakwān, familia de juristas. Poseedor de grandes dotes diplomáticas, supo jugar un papel político importante junto a Almanzor; sin embargo, nunca consintió asistir a la oración del viernes en al-Zāhira, como sucedió con Ibn al-Makwī y otros. Fue cadí en Fah s al-Ballūt (al norte de Córdoba), y șăhib al-radd y mušāwar en la capital, donde ocupó el cargo de cadí supremo en dos ocasiones; de 1001 a 1004, y de 1005 a 1010. Sufrió destierro en Orán (Argelia) durante unos meses de forma injusta, pero volvió a Córdoba, donde se le hizo justicia permitiéndole recuperar su alto cargo junto al califa. Parece ser que este destierro fue el motivo de la muerte de Ibn al-Makwī, según sus biógrafos. Rechazó el nuevo nombramiento de cadí supremo, pero aceptó supervisar la labor de los cadíes hasta su muertc.

5. 'Abd al-Raḥmān b. Muḥammad b. Tsà b. Fuṭays b. Aṣbag b. Fuṭays, Abū l-Muṭarrif, conocido por Ibn Futays (348-402/959-1012)3. . Aristócrata cordobés destacado como

32 Véase $I F(C), \mathrm{n},{ }^{\circ} 1363 ; Y M, 100, \mathrm{n}{ }^{\circ} 170 ; T M$, VII, 114-8; IBN JA Yर, 246; IB, n. ${ }^{\circ} 700 ; D, 136, \mathrm{n} .{ }^{\circ} 325 ;$ Mugrib, $^{\circ}$ 1, 214; DM, II, 230-1; BS, 112; SA. XVI, 411, n. ${ }^{\circ} 298 ; S N$, n. $249 ; S D$, III, 101-2; MU, 77-81, WS, V, n. ${ }^{\circ}$

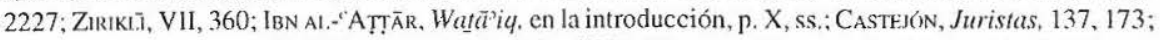
Cano, C. conmututivos, II, 687; Avil.A, Sociedud, n. 834 ; Fúrnfias, Elencos, 49; Antillana, I, 651.

3 Véase $I F(C)$, n. ${ }^{\circ}$ 1390; TM, VI, 307-9; Mugrib, I, 215;MU, 84; SA, XVII, 57, n. ${ }^{\circ} 24$; AvII.A, Bay a, 84, 197; Avil.A, Sociedad, n. ${ }^{\circ} 849$; Fifrro-Zanon, Andalusies, n. ${ }^{\circ} 259$; J. Castill.A, Alumad ibn 'Afif, 113-145, concretamente en 140-1.

4 Véase $Y M, \mathrm{n} .{ }^{\circ} 223 ; T M, \mathrm{VII}, 166-175 ; I B(C), \mathrm{n}^{\circ} 65 ;$ Mugrib, I, 215-6; $B S, \mathrm{n} .^{\circ} 425 ; \mathrm{MU}, 84-7 ; S N, \mathrm{n}^{\circ} 260$; WS, VII, n. ${ }^{\circ} 3052$; E.I. ${ }^{2}$, III, 769, art. por PElI.AT; AvIl.A, Bay $a, 84,96,107,108$; AvII.A, Sociedad, n..$^{\circ} 12$; M.L. Avı.A, «Andalusícs en el Wäfí bi-l-wafayät», en E.O.B.A.. IV, 159-213, especialmente 173.

35 Véase TM, VII, 181-183; IB(C), n. ${ }^{\circ} 682 ; D . \mathrm{n}{ }^{\circ} 976 ;$ Mugrib, I, 216, n. ${ }^{\circ} 146 ; \mathrm{MU}, 87-88 ; D M, \mathrm{I}, 478-9 ;$ SD,

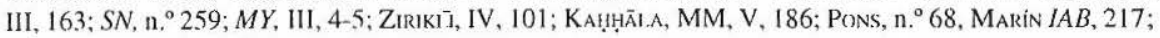
AvII.A, Sociedud, n. ${ }^{\circ} 181$. 
tradicionista y bibliófilo. Transmitió hadices de al-Așīi entre otros, y realizó un viaje a Oriente. Logró formar una gran biblioteca que adquirió justa fama. Fue șăḥib al-mažălim y encargado de la oración y la juṭba. Autor, entre otros, del Kitāb al-masābih fi-fada à̃il al-șahăba. Ocupó el cargo de cadí en dos ocasiones, de 1004 a 1005, y de 1012 a 1013.

6. Yaḥyà b ${ }^{\mathrm{c} A b d}$ al-Raḥmān b. Wāfid al-Yaḥ̣ubīi, Abū Bakr, conocido por Ibn Wāfid (m. 404/1014) $^{36}$. Alfaquí malikí experto en masā̉il y ahkām, aunque también llegó a cultivar la poesía. Alumno, entre otros, de Ibn Abī Zayd con motivo del viaje que realizó para peregrinar a los lugares santos. Se encargó de la oración en Medina Azahara y fue miembro de la süurà cordobesa antes de ser nombrado cadí supremo, cargo que ocupó en dos ocasiones diferentes, de 1010 a 1012, y de febrero a diciembre de 1013. También fue conocido por su actitud antiberéber. Mantuvo algunos enfrentamientos con Almanzor y sufrió su persecución. Al morir Abū 'Umar Ibn al-Makwī llevaba dos días en el cadiazgo cordobés y rezó las oraciones fúnebres por él. Murió en la cárcel.

7. Yunus b. "Abd Allāh b. Muḥammad b. Mugịt b. Muḥammad b. 'Abd Allāh, Abū 1-Walid, conocido por Ibn al-Ṣaffār (338-429/949-1038) ${ }^{37}$. Estudió con los más notables maestros de su época en al-Andalus, como Abū Bakr al-Quṭiyya, el cadí supremo Abū Bakr Ibn Zarb, Abū Bakr al-Zubayd̄̄, Ibn Ab̄̄ Dulaym, etc. También tuvo algunos maestros orientales. Sobresalía entre los alfaquíes y literatos y compuso muchas obras. Fue cadí en Badajoz y luego mušăwwar y șạhịib al-salāt wa-l-jutba en Medina Azahara y Córdoba, antes de ser nombrado cadí supremo. Desempeñó este último cargo dos veces por un total de 9 años y medio, la segunda ocasión hasta su muerte en 1038.

8. Muḥammad b. Jazar ${ }^{38}$. Desconocemos el año de su muerte, pero sabemos que este jefe zanāta compartió el cadiazgo de Córdoba con Ibn al-Șaffăr, de forma interina y sin título específico, en el año 1016.

9. 'Ahdal-Raḥmān b. Aḥmad b. Sacĩd b. Muḥammadb. Bišr b. Garsīya, Abūl-Muṭarrif, más conocido por Ibn Garsīya o Ibn al-Ḥașār (364-422/975-1031) ${ }^{39}$. Prestigioso alfaquí que ocupó durante casi trece años, hasta 1029, el cargo de cadí de la capital con sabiduría. Su origen era muladí.

10. Muḥammad b. Aḥmad b. "Abd Allāh b. Ḥartama b. Dַakwān, Abü Bakr (395-435/ $1005-1044)^{40}$. Hijo del gran jurista Abū l-'Abbās Ibn Dakwān. Tuvo grandes conoci-

36 Véase $I B(C)$, n. ${ }^{\circ} 1457 ; T M$, VII, 176-81, Mugrib, I, 155-7; $M U, 88-9 ; S N$, n. ${ }^{\circ} 262 ;$ AvII.A, Bay a. 84, 96, 97, 108; Avi A, Sociedad, n. ${ }^{\circ}$ 1076; Vigulera, Jueces, 125, ss.

${ }^{37}$ Véase $Y M, \mathrm{n} .{ }^{\circ} 910 ; T M$, VIII, 1.5-19; IB(C), n. ${ }^{\circ} 1512 ; D, \mathrm{n} .{ }^{\circ} 1498 ;$ Mugrib, I, 159; MU, 95-96, DM. II, 3745; SN. n. ${ }^{\circ}$ 307. SD. III, 244; Pons, n. ${ }^{\circ} 84$; Avil.A, Sociedad, 1110 ; Marín, IAB. 222; Vigul:Ra, Jueces. 126 , $129,140,142$.

38 Véasc Mugrib. I, 157; Vigur.RA, Jueces, 126, 129, 132.

39) VÉase $Y M, \mathrm{n} .{ }^{\circ} 588 ; T M$. VIII, 10-11; IB(C). n. ${ }^{\circ} 698 ; D . \mathrm{n} .{ }^{\circ} 993 ;$ Mugrib, I, 158; DM. I, 475-6; SN, n. ${ }^{\circ} 303$; SD, III, 223; AviI.A, Sociedad. n. ${ }^{\circ}$ 162; F. DE I.A GRAnIA, «Ibn García, cadí de los califas hammūdíes», AlAndulus, XXX (1965), 63-78.

4) Véase TM, VIII, 87-88; IB(C). n. ${ }^{\circ} 1150 ;$ Mugrib, I, 70; SN, n. ${ }^{\circ} 298 ;$ E.I. ${ }^{2}$, III, 770, art. por PELI.AT; AvII.A, Sociedad. n. ${ }^{\circ}$ 677; Viguera, Jueces, 128, 140, 143, 144. 
mientos de hadiz y se destacó por su virtud y honradez. Fue nombrado cadí en 1038, cargo que ejerció durante un año. Su nivel personal era bajo.

11. 'Abd Allāh Ibn al-Makwī (m. 448/1056) ${ }^{41}$. Ocupó el cargo de septiembre de 1040 a octubre de 1043, tras estar vacante durante año y medio. Se trata del hijo de Abū ${ }^{c} U m a r$ Ibn al-Makwi, cuya biografía presentaré en el apartado de Discípulos.

\section{Discípulos}

De los numerosos discípulos que siguieron las enseñanzas y opiniones de Ibn alMakwī nos han llegado los nombres que a continuación presento, de los cuales destaco a su sobrino ${ }^{\mathrm{C}} \mathrm{Abd}$ al-Malik y a Ibn al-šaqqāq por su fidelidad:

1. 'Abd al-Raḥmān b. Marwān (o Hārūn) b. 'Abd al-Raḥmān al-Anșārī, Abūl-Mutarrif, conocido por Ibn al-Qanāzici (341-413/952-1022) $)^{42}$. Tradicionista y alfaquí cordobés. Fue alumno de al-Așilli, Ibn al-Qutiyya, Ibn AbīZayd al-Qayrawānīy otros. Viajó a Oriente. Experto en šurlīt, sobre los que compuso un Tratado, y autor también de un Tafsīr, o šarh como dicen otros biógrafos, del Muwatța de Mālik b. Anas. Rechazó el ofrecimiento de formar parte de la šürà de Córdoba.

2. "Abd al-Malik b. Muḥammad b. 'Abd al-Malik b. Hāšim al-Umaw̄ī, Abū l-Aṣbag, conocido también por Ibn al-Makwī (363-425/974-1034) ${ }^{43}$. Era cordobés, aunque sus orígenes familiares se remontan a Sevilla, concretamente a la aldea de $N u \bar{h}$, (nažar Tilyäta), que se encontraba en el distrito de al-Başal, al Oeste de la cora de Sevilla cercano a la cora de Niebla. Sobre sus cualidades nos informan las fuentes que era sobrio y honesto hasta la pureza; además había adquirido válidos conocimientos en ciencia jurídica y era experto en la redacción de documentos notariales ( $w a t \bar{a}^{\top} i q$ ). Transmitió relatos de su tío, el gran muftī Abū 'Umar Ibn al-Makwī, y de él aprendió los elementos básicos de la jurisprudencia malikí. Se le consideró ḥăfiž en los temas por los que sintió interés su tío, gran conocedor de sus opiniones y depositario de sus noticias. El biógrafo especializado en personajes sevillanos Ibn Jazraŷ (m. 478/1085) dijo que este jurista sólo transmitió relatos de su tío.

3. 'Abd Allāh b. Sa'ịd b. "Abd Allāh b. Muḥammad al-Umaw̄in, Abū Muḥammad, conocido por Ibn al-Saqqāq (m. 426/1035) ${ }^{44}$. Personaje de origen ceutí, como nos informa el cadí 'Iyāọ. Dominó varias ramas del saber, pero sobresalió en la redacción de documentos notariales (šurüț). Fue miembro de la šürà cordobesa, uno de sus grandes

41 Véase nota 47.

4: Véase $Y M, \mathrm{n} .{ }^{\circ} 616 ; T M$. VII, 290-3; Ibn Jayr, I, 87; IB(C), n. ${ }^{\circ} 694 ; D$, n. ${ }^{\circ} 1042 ; S D$, III, 198; Mugrib, I, $166-$

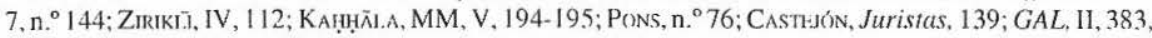
S. II, 403; AvIl.A, Bay a, 89, 110; Avil.A, Sociedad, n. ${ }^{\circ}$ 176; Marín, IAB, 217.

41 Véase $I B(C), n .{ }^{\circ} 771$; AvII A, Sociedad, n. ${ }^{\circ} 135$.

44 Véase $T M$, VII, 295-6: IB(C), n. ${ }^{\circ} 587 ; D$, n. ${ }^{\circ}$ 926; $D M$, I, 437; SD. III, 230; $M Y$. III, 45; AvII.A, Bay a. 89, 96, 111; Avil.A, Sociedad, n. ${ }^{\circ}$ 96: Cano, C. conmutativos, II, 685-6. 
muftíes y cadí en algunas coras andalusíes. Adquirió su formación jurídica de Ibn al Makwī y se convirtió en su más fiel seguidor.

4. Al-Ḥasan b. Muhammad b. Mufarriŷ b. Ḥammād al-Ḥusayn al-Ma āfirìi, al-Qubbas̆ĭ, Abū Bakr, conocido por al-Qubbaš̀ y por Ibn Mufarriŷ (348-d.430/959-d.1039) ${ }^{45}$. Discípulo de Ibn Abī Zamanīn, Ibn Fuṭays, e Ibn al-Hindī, entre otros. Escribió un diccionario biográfico de cadíes, alfaquíes y personajes notables, que parece ser una ampliación de la Historia de Ibn "Afif.

5. 'Abd Allāh b. Yahyyà b. Ahmad b. Daḥḥūn al-Umawī, Abū Muḥammad, conocido por Ibn Daḥ̣ūn (342-432/953-1039) ${ }^{46}$. Originario de Ceuta, como nos informa 'Iyăḍ. Muffı y mušāwar de la escuela malikí de justa fama en Córdoba. Adquirió conocimientos jurídicos de Ibn al-Makwī y fue compañero suyo en la šürà. Destacó en la ciencia del notariado. Tuvo numerosos discípulos, entre ellos cabe destacar a Ibn Hazm.

6. Abū l-Qāsim Aḥmad b. Muḥammad b. Mallās al-Fazāri (370-435/980-1043) ${ }^{47}$. De Sevilla. Viajó a Oriente y allí estudió, entre otros, con Abū Ŷa far al-Dāwudī. En Córdoba fue discípulo de Abū Muḥammad al-Așīi, Ibn al-Makwī, Ibn al-Hindì Ibn al-'Aț̣ār, entre otros. Expero en las ciencias y versado en documentos notariales.

7. "Abd Allāh b. Aḥmad b. 'Abd al-Malik b. Hāšim, Abū Muḥammad, conocido también por Ibn al-Makwī (ca. 378-448/ca. 988-1056) ${ }^{48}$. Natural de Córdoba e hijo de Abŭ 'Umar al-Išbīir. Una de las obras que oyó de Abū Muḥammad b. Asad fue el Șaḥịh de al-Bujārī. También fue discípulo de Abū l-Qāsim al-Wahrānī y otros. Abū l-Hazazm b. Y̧ahwar le adjudicó el cadiazgo en Córdoba después de la dimisión de Abū Bakr b. Dakwān, aunque mostró cierta resistencia a ser nombrado cadí, tal vez por influjo de laépoca, hecho considerado normal entonces, o por la influencia de la renuncia tajante de su padre en dos ocasiones. Aquello sucedió el día 7 de muharram de 432/17 de septiembre de 1040.

Mientras desempeñó el cargo de cadí no destacó por realizar nada digno de mención, excepto el hecho de negarse a poner en manos del régulo cordobés el control de las instituciones pías o bienes habices (ḥubus), y otros tesoros (majāzin) de la Aljama. Realmente poseía escasa ciencia y conocimientos, de tal manera que su nombramiento para el cadiazgo no se basaba en su prestigio personal, sino más bien en la posibilidad de ser fácilmente influido por Ibn Ŷahwar. Su situación se complicó por el menosprecio de la mayoría de los notables cordobeses. Abū 'Umar Ibn al-Qațtān ${ }^{49}$ colaboró con él en la emisión de sus dictámenes jurídicos y resoluciones judiciales.

45 Véase $I B(C)$, n. $^{\circ} 311$; Pons, n. ${ }^{\circ} 86$; Avil.A, Sociedad, n. ${ }^{\circ}$ 448; Castil. A, Ibn 'Afif, 144.

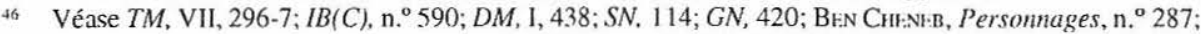
Castr.ón, Juristas, 60, 81; Avil. A, Bay a, 89,96; Avil..A, Sociedad, n. ${ }^{\circ} 104$; Cano, C. conmutativos, II, 6701.

47 Véase $I B(C), \mathrm{n} .^{\circ} 102$.

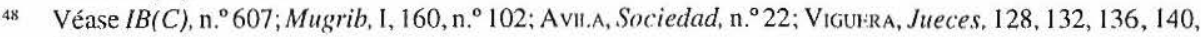
144.

49 Se trata de Ahmad b. Muhammad b. 'Isà b. Hilāl al-Qurțubī, Abū 'Umar, conocido por lbn al-Qạtān (m. 460/1068). Muff̆ y mušāwar que gozó de prestigio en Córdoba, discípulo de Ibn Daḥhūn e Ibn al-šaqqāq 
Lo destituyó de tal cargo Abū 1-Walid Muhammad b. Yahwar, el día 17 de rab̛̆̃ $I$ de $435 / 24$ de octubre de 1043, quedando, a partir de entonces, en la oscuridad y sin ocupación. Fue atacado por una enfermedad que le ocasionó una gran y penosa debilidad y que, después de repetirle en varias ocasiones, le produjo la muerte. Parece ser la epidemia que tuvo lugar en Córdoba en aquel año. Sus restos fueron inhumados en el cementerio de Umm Salama al atardecer del día 13 de ŷumädà $I$ del año 448/29 de julio de 1056. Asistió a su entierro un grupo numeroso de gente que lo elogió por su sobriedad y su modestia. Contaba con setenta años de edad aproximadamente y estuvo al frente del cadiazgo durante tres años, dos meses y doce días.

8. Yūsuf b. 'Abd Allāh b. Muḥammad b. 'Abd al-Barr al-Namarī, al-Qurtubīi, Abū 'Umar, conocido por Ibn ${ }^{\mathrm{C}} \mathrm{Abd}$ al-Barr (368-463/978-1071) ${ }^{50}$. Siguió los principios de la escuela zăhirī en un principio, pero más tarde evolucionó hacia el malikismo incorporando también ciertos elementos šăficíes. Fue considerado como uno de los andalusíes más versados en fiqh y haditit, aunque se valoran más sus conocimientos de tradición. No realizó ningún viaje a Oriente, aunque mantuvo contactos con maestros orientales, de los cuales también recibió iŷazza. Se vió obligado a marchar de Córdoba y se estableció en Lisboa y Santarem, donde ejercició el cargo de cadí. Fue autor de numerosas obras de contenido jurídico-religioso, literario y genealógico. Finalmente se trasladó hasta Játiva y allí murió.

\section{SU MUERTE}

Ibn al-Makwī falleció el domingo día 7 de ŷumādà I de 401/17 de diciembre de 1010 . Se nos ofrece por parte de 'Iyāḍ una razón un tanto extraña de la muerte de nuestro personaje. Según él falleció por el abatimiento tan profundo en el que cayó, a causa de la desgracia que sufrieron los Banū Dakwān ${ }^{51}$. De tal forma le afectó, que murió a los pocos días de suceder tal hecho. La calamidad a la que se refiere 'Iyād está relacionada con el asalto a Madinat al-Zahrä' realizado por los beréberes un mes antes, ya que el califa cordobés Hišām II destituye a Aḥmad b. D_akwān del cadiazgo supremo por razones políticas, puesto de Ibn Dakwān se mostraba partidario de entablar negociaciones con los beréberes. Incluso fue acusado y calumniado de mirarlos con simpatía, mientras que el califa deseaba tener a su lado a un cadí intransigente y opuesto a los asaltantes, como de hecho fue el nuevo cadí supremo Ibn Wāfid. Por este motivo tanto Abū l-cAbbās Ibn Dakwān, como su hermano Abū l-Ḥātim fueron destituidos de sus cargos, en primer lugar,

y, por tanto, también relacionado con Abū cUmar Ibn al-Makwī. Véase TM. VIII, 135-6; IBN JAYR, 24I; $I B(C)$. n. ${ }^{\circ} 130 ; D M, 1,181-2 ; S N, 119 ; S A$, XVIII, 305-6, n. ${ }^{\circ} 145$; FIfrro-Zano, Andalusies, n. ${ }^{\circ} 89$; J.M. FórNl:AS, "Datos para un estudio de la Mudawwana de Sahnnün en al-Andalus», Actas del IV Coloquio Hispano-Tunecino (Madrid 1983), 93-118, nota 81: Avil.A, Bay'a. 111-2; CANo, C. conmutativos, II, 682. VÉase $Y M, \mathrm{n} .{ }^{\circ} 874 ; I B(C), \mathrm{n} .{ }^{\circ} 1501 ; D, \mathrm{n} .{ }^{\circ} 1442 ; S D$. III, 314; Marín, IAB, 206-210.

st Véase $T M$, VII, 301, en la biografía de Abū l-Qāsim Ibn Nabīl, de quien se dice que también falleció por la misma causa. 
y desterrados al Norte de Africa, después. Sucedió en 404/1010 y se marcharon a Orán (Argelia).

Con todo, el propio 'Iyād cree que el motivo de su fallecimiento ha sido exagerado por la gente. Podemos observar, a pesar de todo, la ironía del destino, porque si nuestro personaje falleció, podemos comprobar que el propio afectado, Aḥmad b. Dakwān, superó la afrenta y continuó viviendo hasta el año 413/1022.

De lo que no hay duda es de que su muerte fue considerada como inesperada y repentina. Su cortejo fúnebre estuvo formado por una gran muchedumbre que le apreciaba. Ibn Baškuwāl dice que su cuerpo fue lavado por Abū ${ }^{\mathrm{c} U m a r} \mathrm{Ibn}^{\mathrm{c}} \mathrm{Afiff}$, y al entierro asistió el hââyib de Hišām b. al-Ḥakam, cargo que en ese momento ejercía Wăḍiḥ ${ }^{52}$. El cadí supremo Ibn Wāfid dirigió las oraciones fúnebres en el cementerio de Qurays̆, donde fueron inhumados sus restos.

\$2 Esclavo 'ämirīı gobernador de la Marca Media desde su sede de Medinaceli, que tuvo cierto protagonismo político en esa época inestable y turbulenta. Véase Levi-Provençal, Esp. musulmana, IV, 468-471. 